UDC. $577.21 ; 636.082 .12$

\title{
GENETIC CHARACTERIZATION OF THE MIRGOROD PIG BREED, OBTAINED BY ANALYSIS OF SINGLE NUCLEOTIDE POLYMORPHISMS OF GENES
}

\author{
P. A. Vashchenko, V. M. Balatsky, K. F. Pocherniaev *, V. M. Voloshchuk, \\ V. H. Tsybenko, A. M. Saenko, Ye. K. Oliynychenko, T. V. Buslyk, H. S. Rudoman \\ The Institute of Swine Production and Agroindustrial Production, NAAS of Ukraine \\ 1, Shvedska mohyla Str., Poltava, 36013, Ukraine \\ E-mail: k.f.pochernyaev@gmail.com*
}

Received May 16, 2019 / Received June 21, 2019 / Accepted July 19, 2019

\begin{abstract}
Aim. To determine genetic characteristics of the Mirgorod pig breed by analysis of 25 SNPs of 22 genes and to conduct the associative analysis of genes MC4R (SNP c.1426 G > A), LEP (SNP g.2845 A > T), GH (BsuRIpolymorphism), CTSF (SNP g. $22 \mathrm{G}>\mathrm{C}$ ) with productive traits of animals. Methods. Blood samples of pedigree Mirgorod pigs, bred at SI «Experimental farm named after Decemberists», Poltava region, were used for the studies. DNA genotyping was performed by PCR-RFLP and TaqMan. Results. Specific features of the breed were determined in terms of gene allele frequencies, high level of genetic variability $(\mathrm{He}-0.326)$ and allelic diversity (mean number of alleles per locus - 1.96). The KPL2/m allele that causes genetic anomaly of ISTS is absent among investigated Mirgorod pigs, and the recessive RYR1 g.1843T allele, responsible for stress sensitivity of pigs, occurs at a low frequency (0.04). Unlike other breeds, a relatively high frequency of the minor allele g.15A (0.16) of CTSK and polymorphism of the LEP gene (SNP g.3996 T > C) ( He - 0.455) was observed. Statistically significant associations of polymorphisms have been established: $M C 4 R$ (SNP c.1426 $\mathrm{G}>\mathrm{A}$ ) with age of gaining $100 \mathrm{~kg}$, the thickness of backfat and the Eye Muscle Area, GH/BsuRI with the age of gaining $100 \mathrm{~kg}$, and CTSF (SNP g. 22G $>$ C) with Eye Muscle Area. There was a trend of statistically significant differences between groups of pigs with different genotypes of LEP (SNP g.2845 A > T) and the thickness of the backfat $(p=0.09)$. Conclusions. It is reasonable to carry out the restoration of the gene pool of the Mirgorod pig breed, taking into account the SNPs of the studied genes and their associations with the productive traits. It is expedient to give preference to pigs with SNP genotypes c.1426 MC4R GA, MC4R AA, g. 22 CTSF CC, g.2845 LEP TT for breed reproduction.
\end{abstract}

Keywords: Mirgorod pig breed, genetic characteristics, QTL, SNP.

DOI: https://doi.org/10.15407/agrisp6.02.047

Introduction. One of negative consequences, resulting from the distribution of industrial technology of animal production, has become the decrease in genetic diversity of agricultural breeds. In pig breeding, the main bulk of the global livestock is presented with three breeds - Large White (Yorkshire), Landrace and Duroc. In general, these breeds are more productive and better adapted to the conditions of industrial technology compared to local ones. However, local breeds, most of which are at the verge of extinction, have some unique traits, which could be useful in

(C) P. A. VASHCHENKO, V. M. BALATSKY, K. F. POCHERNIAEV, V. M. VOLOSHCHUK,V. H. TSYBENKO, A. M. SAENKO, Ye. K. OLIYNYCHENKO, T. V. BUSLYK, H. S. RUDOMAN, 2019 case of changes in economic conditions and the loss of which could result in depauperation of the global gene fund of animals. Among these traits of local breed pigs, one can distinguish high adaptation and resistance abilities, conformational and performance stability, high viability, plasticity, plain feeding, excellent reproduction and maternal characteristics, high product quality [1-3].

Mirgorod pig breed is one of such local breeds, which has come to the verge of extinction, regardless of unique useful characteristics. This breed was approved in 1940. It was obtained via complicated reproductive crossing of local short-eared pigs with English breeds Berkshire, Tamworth, Middle Large, and Large White. Long-term mass selection while breeding local pigs of 
Poltava region «within themselves» played a great role in the process of establishment $[4,5]$.

It is well known that the content of intramuscular fat is one of the main factors, impacting the tenderness and energy value of meat. According to the data, presented in the articles [6-8], muscular tissue of purebred Mirgorod pigs contains extra-high level of intramuscular fat $(6.56 \%)$ and is remarkable for a low content of proteins $(20.33 \%)$. Along with low content of moisture in the meat of this breed, this trait conditions its excellent taste qualities. In addition to the abovementioned, another specific feature of this breed is its ability to use pastures and a considerable percentage of non-concentrated fodder in the ratio [9]. This is conditioned by the fact that Mirgorod breed was established on the basis of local pigs, which had been better adapted to digesting fibers.

Until recently, the main problem in preserving the gene fund of Mirgorod breed was its low number of livestock and, as a result, forced use of in-breeding in its selection.

However, the situation was not critical. The studies, conducted in 2010-2014, noted a low degree of inbreeding, and thus, a possibility of purebred selection without the risk of inbred depression [9]. This conclusion is also confirmed by the analysis of microsatellite loci of Mirgorod breed, which determined that its genetic variability was high, but lower $\left(\mathrm{Na}=2.92 ; \mathrm{H}_{\mathrm{o}}=\right.$ $=0.382$; FIS $=0.178$, compared to three other Ukrainian local pig breeds - Ukrainian Meat, Ukrainian White Steppe and Ukrainian Spotted Steppe (mean $\mathrm{Na}=5.00$ 8.42; $\left.\mathrm{H}_{\mathrm{o}}=0.549-0.668 ; \mathrm{FIS}=0.027-0.066\right)$ [10].

However, the spreading of African swine fever (ASF) in Ukraine has become the highest threat for breed preservation. According to the data of the World Organization for Animal Health [11], since the beginning of 2016, 123 thousand pigs were eliminated in Ukraine due to the outbreak of ASF, not counting the ones, eliminated in private households.

In August 2018, the only purebred herd of Mirgorod pig breed in the world, which belonged to SI "EF named after Decemberists" was eliminated too, due to the outbreak of ASF. As of December 2018, only 9 animals of Mirgorod breed remained alive in the experimental station of the Institute of Swine Production and Agroindustrial Production, NAAS, and 14 pigs in private households. In addition, the genetic material bank of the Institute of Animal Breeding and Genetics, NAAS, keeps the sperm of 5 Mirgorod breed boars, obtained in 2016. Therefore, there are some prerequisites for restoration of Mirgorod breed. Here, one of possible constituents of solving this task is using the genetic material of Belorussian Black-and-Spotted pig breed, the selection scheme of establishing of which was similar to the scheme of establishing the Mirgorod breed, and which is close to the latter by the phenotype features. Another possibility is the involvement of Poltava Meat breed, which was created using Mirgorod breed sows and inherited specific mitochondrial haplotype from the latter. It is important for the population of the restored breed to be maximally genetically similar to the initial Mirgorod breed, which is practically nonexistent at present.

Taking this fact into consideration, it is relevant to obtain genetic characteristics of the Mirgorod breed using the information about single nucleotide polymorphisms. Genetic characterization is supplemented with the associative analysis of the relationship between some SNPs and the manifestation of productive features of purebred pigs.

\section{MATERIALS AND METHODS}

The population studies involved the use of blood samples of pedigree Mirgorod pigs, bred at SI «Experimental farm named after Decemberists», the Institute of Swine Production and the Agroindustrial Production of NAAS in Poltava region, which were obtained in 2015-2017. The number of pigs, genotyped by each gene under investigation, is presented in Table 1.

The association of genetic markers with productive traits was determined for the pigs of Mirgorod breed (the breeding farm of SI «Experimental farm named after Decemberists»),yusing the following indices: age of reaching the bodyweight of $100 \mathrm{~kg}$ (days), thickness of backfat, measured at the level of vertebrae 6-7 $(\mathrm{mm})$ at the bodyweight of $100 \mathrm{~kg}$, average daily gain (g) during the feeding period, length of a semi-carcass (cm) and Eye Muscle Area (sq.cm.). DNA from blood samples was extracted using Chelex 100 reagent [12].

DNA-typing using PCR-RFLP by gene ESR1 (genetic marker $E S R 1 / P v u I I)$ was performed according to [13], by gene $R Y R 1$ (g.1843C > T SNP) [14], PRLR (PRLR/Alu I, SNP c.1789 G > A) [15], GH(GH/BsuRI) [16], IGF2 (IGF2/NciI (BcnI) [17], GHRH (GHRH/ Alu1) [18], CTSB (g. 72 A > C SNP) [19], CTSL (g.143C > T SNP) i CTSS (g.171G > A SNP) [20], CTSF (SNP g. $22 \mathrm{G}>\mathrm{C}$ ) [21], $M C 4 R(\mathrm{c} .1426 \mathrm{G}>\mathrm{A}$ ) [22], LEP (SNP g.2845 A > T) and LEP (SNP g.3996 $\mathrm{T}>\mathrm{C})$ [23], LEP $(\mathrm{SNP}$ g.3469 T > C) [24], LEPR 
GENALEX 6 program was used to estimate population characteristics [31]. The analysis of associations between genotypes and indices of productive traits of pigs was conducted using single-factor disperse analysis (ANOVA, analysis of variance) in Excel 2007.

\section{RESULTS AND DISCUSSION}

Table 1 presents the frequencies of alleles of 22 genes of quantitative trait loci, determined both by the results of our own genotyping of pedigree stock of Mirgorod pig breed, and in the investigations of other authors, the works of which have been referenced.

The analysis of allele frequencies demonstrated some specificities of the Mirgorod breed in comparison with local and transborder breeds of different performance lines [34].

For instance, by ryanodine receptor 1 gene ( $R Y R \mathrm{I})$, the frequency of minor allele g.1843T, associated with the hereditary drawback of pigs - enhanced stress sensitivity, the critical manifestation of which is malignant hyperthermia [14], was 0.04 . However, the phenotypic manifestation of the mentioned allele was not registered in the Mirgorod breed herd. At the same time, allele g.1843 T is absent in local breeds - Ukrainian White Steppe and Ukrainian Spotted Steppe, and in meat breeds it occurs with the frequency from 0.1 to 1.00 .

Estrogen receptor 1 gene (ESR 1), traditionally viewed as a genetic marker of reproductive qualities of sows ( $P v u$ II-polymorphism of 3rd intron of the gene) [35-37] in the Mirgorod breed, was remarkable for polymorphism similar to most other domestic and foreign breeds. However, according to our data, contrary to the Large White breed, the «desired» allele ESR 1 was not associated with multiple pregnancy of sows in the Mirgorod breed.

Enhancing reproductive traits in pig breeding involves the use of genetic markers, based on polymorphism of prolactin receptor gene ( $P R L R, A l u \mathrm{I}$-polymorphism, SNP c.1789 G>A) [38] and follicle-stimulating hormone beta-subunit gene, HaeIII-polymorphism) [39]. According to our data and the results, obtained in the work [40], the mentioned genes are notable for polymorphism in the Mirgorod breed; no specificities in terms of allele frequencies and differences from other breeds were determined.

According to the data, presented in [40], secreted phosphoprotein 1 gene $(O P N$ or $S P P 1)$ [41], which has registered impact on such reproductive traits of pigs as a number of piglets at birth and motility of spermia in boars, was notable for not a high level of polymorphism (indel in SINE element) at the frequency of a minor allele $\mathrm{A}-0.136$. The distribution of allele frequencies in the population of the Mirgorod breed had slight differences from that for Large White, Large Black, Poltava Meat and Landrace breeds.

As for the growth hormone gene $(G H)$, involved in the control of meat and finishing qualities of pigs [42], as of 2017, both alleles of the gene (BsuRI-polymorphism) were found in the population of the Mirgorod breed, whereas our previous studies of this breed did not determine allele B of this marker. Allele B was absent in local breeds of Ukrainian White Steppe and Ukrainian Spotted Steppe, and in a number of other breeds, produced in Ukraine, this gene occurred with different frequencies of alternative alleles.

In terms of a physiological function of encoded proteins and localization of some QTLs in regions, cathepsin genes are referred to the candidate genes, involved in the control of meat productivity traits, meat quality and carcass structure [19-21, 43-46]. As for allele frequencies of cathepsin genes S, F, and B, the Mirgorod breed does not have any significant differences from other domestic and foreign breeds, for which relevant population studies were conducted [47]. At the same time, its specificity was a relatively high frequency of the minor allele $A$ by SNP of gene CTSK g. $15 \mathrm{G}>\mathrm{A}$ $(q=0.16)$ and practically no polymorphism of gene CTSL by SNP g.143C $>$ T $(q=0.01)$.

Leptin genes $(L E P)$ and leptin receptor genes ( $L E P R)$ are also candidate genes to QTL, as they play an important role in regulating lipid exchange [48, 49]. In the Mirgorod breed, allele frequencies by genetic markers LEPR (SNP c. 1987C > T) and LEPR (SNP c.232T>A), associated with the features of finishing and meat traits, had no significant differences from the frequencies of these alleles in the populations of other breeds, in particular, in Large White, according to the data, obtained in [32]. Among genetic markers of leptin gene SNP g.2845 A > T, SNP g.3469 T>C and SNP g.3996 T >C, the Mirgorod breed differed from other breeds in terms of allele frequency only by the latter. For instance, Yorkshire and Large White breed of Ukrainian selection had only one allele (LEP g.3996 C) [23], whereas the Mirgorod breed demonstrated the prevalence of allele LEP g.3996 T.

Melanocortin 4 receptor gene (MC4R) (SNP c.1426 $\mathrm{G}>\mathrm{A})$ ) and growth hormone-releasing hormone gene $(G H R H)($ Alul-polymorphism), impacting the finishing traits of pigs and fat deposition $[50,51]$ in the Mir- 
gorod breed were characterized by a considerable level of polymorphism by the corresponding genetic markers. However, these genes were also polymorphic in a number of other breeds, bred in Ukraine [52, 30].

Genes, impacting the processes of fat deposition, include perilipin gene (PLIN) [53]. According to [40] polymorphisms SNP g.4119A $>$ G and SNP g.7966T > $>\mathrm{C}$ occurred in the Mirgorod breed with rather high frequencies of alternative alleles (Table 1), which were close to the frequencies of these alleles in the Large White breed.

Actinin alpha 1 gene $(A C T N 1)$, associated with the development of muscle tissue, meat quality and reproductive traits, was represented in the population of Mirgorod breed by two alleles $\mathrm{G}$ and A (BstE II - polymorphism) with the prevalence of the former [40], which did not distinguish it from other breeds, investigated by this locus [54].

The mutant allele of calpastatin 2 gene (KPL2/m), which differs from the normal («wild» type), by the insertion of transposon in the area of intron 30, and is known to be responsible for immotile, short-tail sperm defect (ISTS) in boars, was not found in the population of the Mirgorod breed [55]. This defect is manifested in animals, homozygous by the mutant allele, and in Finnish Yorkshire, mainly. It has recently been demonstrated that the carriers of this allele may be pigs of other breeds [56].

Mucin 4 gene (MUC4) encodes mucin 4 - glycoprotein, playing a relevant role in protecting intestinal epithelium from pathogenic microorganisms, in particular, from adhesive strains of Escherichia coli. A point replacement of g. $1849 \mathrm{G}>\mathrm{C}$ in intron 7 of the gene conditions the existence of two alleles, including g. $1849 \mathrm{G}$, associated with the resistance of pigs to Escherichia coli bacteria, causing colibacteriosis [57]. One of the specificities of the Mirgorod pig breed was found to be high frequency of allele g. $1849 \mathrm{G}$ of mucin 4 gene. Contrary to a number of other breeds, it was 0.8 , whereas, for instance, in the populations of the Large White the allele g.1849 G frequency was in the range of $0.16-0.67$ [58].

Fucosyltransferase 1 gene (FUT1), encoding $\alpha$-fucosyltransferase 1 , is also associated with the resistance of pigs to diseases, caused by coliform bacilli. The animals, homozygous by recessive allele A of gene FUT1 (SNP g.307 G>A), are notable for resistance to colibacteriosis, the mutation of gene $\mathrm{G} \rightarrow \mathrm{A}$ in position 307 b.p. is «desired» in pigs. In the Mirgorod breed, the frequency of allele g.307 A was at the level, close to the frequency of this allele in Duroc breed (0.21 and 0.28, respectively), and in different populations of the Large White it was in the range of $0.06-0.43$ [27]. Thus, no specific features in terms of the distribution of gene FUT1 alleles were found in the Mirgorod breed.

In general, the analysis of 25 SNPs of 22 genes demonstrated a high level of genetic variability in the population of pigs of Mirgorod breed. Only three out of all the investigated genes were found to be monomorphic (the accepted criterion of polymorphism was the frequency of a minor allele $\geq 0.05$ ). Therefore, the percentage of polymorphic loci was $88.0 \%$ with the consideration of several polymorphisms, present in one gene. To compare the Mirgorod breed against other breeds (in particular, Large White of different selection, Large Black, Landrace, Ukrainian White Steppe, Ukrainian Spotted Steppe, and Poltava Meat), the percentage of polymorphic loci was calculated separately for 12 genes of QTL from the investigated ones, namely, the ones, previously used by us for genotyping in subpopulations of these breeds (RYRI, ESR1, PRLR, GH, IGF2, CTSB, CTSK, CTSS, CTSL, MC4R, GHRH, LEPR) [47, $30]$. In this case, the percentage of polymorphic loci in the Mirgorod breed was $83.3 \%$, whereas, for instance, in different subpopulations of Large White (of English selection and intrabreed types of ULW-1 and ULW-3) it fluctuated in the range of $58.3-66.7 \%$, in the population of Large Black - $75.0 \%$. The percentage of polymorphic loci was also lower $(75 \%$ and $50 \%$, respectively) in the local breeds, Ukrainian White Steppe and Ukrainian Spotted Steppe, which are «closed» and in which the selection is conducted similar to that for the Mirgorod breed, mostly without the involvement of genetic material of other breeds.

Noteworthy is the fact that the average expected heterozygosity $\mathrm{H}_{\mathrm{e}}$ (Nei's genetic diversity) was at a relatively high level -0.326 , which is another feature of high genetic variability in the Mirgorod breed. The latter is also confirmed by the average number of alleles per locus -1.96 and the effective number of alleles -1.48 .

In addition, a high level of QTL gene polymorphism in the population of the Mirgorod breed, as one of the factors of genetic variability, is indicated by the indices of PIC, estimated for each genetic marker, used for typing. For instance, PIC values of 17 out of 25 genetic markers in the investigated population were at the level, exceeding 0.250 , which corresponded to their high informative value, sufficient to conduct associative studies in marker-associated selection [59]. 
The abovementioned data demonstrate the absence of genetic erosion and contraction of genetic variability in the population of pigs of Mirgorod breed. This is in good agreement with the conclusions, obtained via the analysis of its genetic structure by immunological [60] and ISSR [61] markers and microsatellite loci [10]. This also corresponds to the conclusion, made by the results of the analysis of genealogy of intrabreed structures about the possibility of avoiding affinity breeding and preserving the gene fund [62].

More detailed genetic characterization of the Mirgorod breed involved the analysis of the association of specific genetic markers with the main productive traits of the pigs of Mirgorod breed (Table 2). The animals of the experimental group under investigation were estimated by five parameters of the productive traits and genotypes by genetic markers IGF2/NciI (BcnI), RYRI $(\mathrm{SNP}$ g.1843C > T), MC4R (SNP c.1426 G > A), LEP (SNP g.2845 A > T), GH/BsuRI, CTSF (SNP g. $22 \mathrm{G}$ $>C)$. By the first two markers, all the animals in the experimental group had similar genotypes, IGF2 AA and RYRI g.1843CC, respectively. As for the rest of genetic markers, pigs were divided into groups in accordance to the genotypes, among which the groups of animals with genotypes $M C 4 R$ c. 1426 GG and $G H$ BB were absent. Unfortunately, the latter is explained by a small sampling of the animals for associative analysis.

It was determined that there were statistically significant associations of the genetic marker $M C 4 R$ SNP c.1426 G>A with such indices as the age of gaining $100 \mathrm{~kg}$, the thickness of backfat and the Eye Muscle Area. We also determined the associations between the growth hormone gene polymorphisms $(G H / B s u R I)$ and the age of gaining $100 \mathrm{~kg}$ and cathepsin gene $\mathrm{F}$ (CTSF SNP g. $22 \mathrm{G}>\mathrm{C}$ ) with the Eye Muscle Area. There was a tendency, observed for statistically significant differences between the groups of pigs with different genotypes by leptin gene (SNP g.2845 A > T) by thickness of backfat $(p=0.09)$. For comparison, there was no association between the genetic marker LEP SNP g.2845 $\mathrm{A}>\mathrm{T}$ and thickness of backfat in the Large White.

The results regarding the association of SNP and the productive traits for Mirgorod breed with the consider-

Table 2. The associations of genetic markers and productive traits of the Mirgorod breed pigs

\begin{tabular}{|c|c|c|c|c|c|}
\hline \multirow[b]{2}{*}{ Genotype } & \multicolumn{5}{|c|}{ Productive traits } \\
\hline & $\begin{array}{l}\text { Age of gaining } \\
100 \mathrm{~kg} \text { (days) }\end{array}$ & $\begin{array}{l}\text { Thickness of } \\
\text { backfat }(\mathrm{mm})\end{array}$ & $\begin{array}{l}\text { Average daily } \\
\text { gain }(\mathrm{g})\end{array}$ & $\begin{array}{l}\text { Length of semi- } \\
\text { carcass }(\mathrm{cm})\end{array}$ & $\begin{array}{c}\text { Eye Muscle Area } \\
\text { (sq.cm.) }\end{array}$ \\
\hline \multicolumn{6}{|c|}{$M C 4 R S N P$ c. $1426 G>A$} \\
\hline $\begin{array}{c}A A \\
A G \\
P\end{array}$ & $\begin{array}{c}210.3 \pm 4.61 \\
196.5 \pm 3.12 \\
0.03\end{array}$ & $\begin{array}{c}32.8 \pm 1.02 \\
29.3 \pm 0.86 \\
0.02\end{array}$ & $\begin{array}{c}575.0 \pm 22.47 \\
621.1 \pm 40.22 \\
0.33\end{array}$ & $\begin{array}{c}93.9 \pm 1.57 \\
94.5 \pm 0.64 \\
0.76\end{array}$ & $\begin{array}{c}31.7 \pm 1.01 \\
34.3 \pm 0.64 \\
0.05\end{array}$ \\
\hline \multicolumn{6}{|c|}{ LEP SNP g.2845 $A>T$} \\
\hline $\begin{array}{c}A A \\
T A \\
T T \\
P\end{array}$ & $\begin{array}{c}195.6 \pm 3.81 \\
209.3 \pm 4.88 \\
200.1 \pm 2.97 \\
0.13\end{array}$ & $\begin{array}{c}29.4 \pm 0.91 \\
32.6 \pm 1.10 \\
29.4 \pm 1.40 \\
0.09\end{array}$ & $\begin{array}{c}579.5 \pm 31.50 \\
606.3 \pm 30.98 \\
602.7 \pm 76.92 \\
0.89\end{array}$ & $\begin{array}{c}93.3 \pm 1.55 \\
93.4 \pm 0.63 \\
97.0 \pm 3.60 \\
0.30\end{array}$ & $\begin{array}{c}33.0 \pm 0.85 \\
32.2 \pm 0.75 \\
34.9 \pm 0.77 \\
0.12\end{array}$ \\
\hline \multicolumn{6}{|c|}{$G H / B s u R I$} \\
\hline $\begin{array}{c}A A \\
A B \\
P\end{array}$ & $\begin{array}{c}199.7 \pm 2.33 \\
205.5 \pm 6.23 \\
0.03\end{array}$ & $\begin{array}{c}31.1 \pm 0.94 \\
31.2 \pm 1.54 \\
0.78\end{array}$ & $\begin{array}{c}581.3 \pm 22.54 \\
633.7 \pm 56.25 \\
0.57\end{array}$ & $\begin{array}{c}94.1 \pm 1.32 \\
94.7 \pm 1.60 \\
0.88\end{array}$ & $\begin{array}{c}33.2 \pm 0.69 \\
33.2 \pm 0.83 \\
0.53\end{array}$ \\
\hline \multicolumn{6}{|c|}{ CTSF SNP g. $22 G>C$} \\
\hline $\begin{array}{c}C C \\
G C \\
G G \\
P\end{array}$ & $\begin{array}{c}201.3 \pm 4.30 \\
214.6 \pm 8.87 \\
200.1 \pm 3.01 \\
0.25\end{array}$ & $\begin{array}{c}31.9 \pm 1.22 \\
29.4 \pm 0.74 \\
30.2 \pm 0.99 \\
0.44\end{array}$ & $\begin{array}{c}571.5 \pm 21.15 \\
610.5 \pm 36.97 \\
\Gamma 643.7 \pm 69.26 \\
0.42\end{array}$ & $\begin{array}{c}94.9 \pm 1.52 \\
92.8 \pm 1.17 \\
93.4 \pm 1.42 \\
0.67\end{array}$ & $\begin{array}{c}33.9 \pm 0.63 \\
30.8 \pm 1.23 \\
32.4 \pm 0.81 \\
0.04\end{array}$ \\
\hline
\end{tabular}

Note. The data are presented as LSMeans \pm SEM; the values of $P$ in italics correspond to statistically significant differences between the groups. 
ation of a small sampling of the experimental animals may be viewed as preliminary data only and should have been validated using a larger number of animals. However, the elimination of the purebred herd and a limited number of remaining Mirgorod breed pigs exclude this possibility. However, the associations, determined in our study, give some ideas about the search for genetic markers of productive traits in pigs of the restored population of the Mirgorod breed for markerassociated selection.

Therefore, the results of the studies on genetic structure of the Mirgorod breed by a number of SNPs and associative analysis demonstrate its specificities and differences from other breeds, bred in Ukraine. First of all, these specificities refer to the general high level of genetic variability, determined by the results of our analysis of SNPs. This is in agreement with the statements of other authors about the Mirgorod breed, whose genetic structure was studied using other classes of genetic markers. The abovementioned proves the common thesis about local breeds, preserving higher level of genetic variability compared to the commercial breeds. The latter are subject to considerable breeding impact, aimed at the maximal manifestation of productive traits, which may result in some contraction of allelic diversity in their populations [63].

It should also be noted that the Mirgorod breed is remarkable for the absence of the mutant allele $K P L 2 / \mathrm{m}$, conditioning genetic anomaly of ISTS, and the recessive allele $R Y R 1$ g.1843T, associated with stress sensitivity of animals, is present with very low frequency (0.04). The latter is the consequence of «new incoming blood» of Pietren - the breed, which was not included into the breeds-founders of the Mirgorod breed. It should be considered that the specificity of the breed is rather a high frequency of the minor allele CTSK g.15A $(q=0.16)$ and, thus, rather a high level of informative value of the genetic marker CTSK (SNP g.15G > $>\mathrm{A})(\mathrm{PIC}=0.233)$. Noteworthy is the polymorphism of gene $L E P$ in the Mirgorod breed by the genetic marker of SNP g.3996 T > C, which distinguishes it from the Large White.

\section{CONCLUSIONS}

The associations between some genetic markers and productive traits have been determined in the herd of the Mirgorod breed. On the one hand, these associations may result from the immediate impact of polymorphisms of quantitative trait nucleotides (QTN) on their manifestation. However, they may be considered as a specific case of population dynamics process, due to which there are changes in the frequencies of alleles in the sampling not only by the candidate genes of QTL, but also by a number of others, functionally related or linked to them. The latter is relevant in the context of preserving genetic structure and variability of breeds to prevent the loss of their breed specificity, which is especially urgent for numerically insignificant local breeds. In both cases, in our opinion, it is reasonable to check the presence of the very associations, determined in the original breed, during the breeding process using genetic markers in the restored population of the Mirgorod breed.

It is reasonable to carry out the restoration of the gene pool of the Mirgorod pig breed, taking into account the results regarding the SNPs of the studied genes and their associations with the productive traits, presented in this article. The selection of animals for restoration should be carried out after typing the young animals, giving preference to pigs with genotypes c.1426 $M C 4 R^{\mathrm{GA}}, M C 4 R^{\mathrm{AA}}$, g. $22 C T S F^{\mathrm{CC}}$, g. $2845 L_{E P}{ }^{\mathrm{TT}}$.

\section{Генетична характеристика миргородської породи свиней, отримана шляхом аналізу однонуклеотидних поліморфізм генів}

П. А. Ващенко, В. М. Балацький, К. Ф. Почерняєв*, В. М. Волощук, В. Г. Цибенко, А. М. Саєнко, Є. К. Олійниченко, Т. В. Буслик, Г. С. Рудоман

Інститут свинарства і агропромислового виробництва НААН України, Вул. Шведська могила, 1 , Полтава, 36013, Україна

*e-mail: k.f.pochernyaev@gmail.com

Мета. Визначити генетичні характеристики миргородської породи свиней за 25 SNPS 22 генів та провести асоціативний аналіз генів $M C 4 R$ ( $S N P$ c.1426 $G>A)$, LEP (SNP g.2845 A>T), GH (BsuRI-поліморфізм), CTSF $(S N P$ g. $22 G>C) 3$ ознаками продуктивності тварин. Методи. Для досліджень були використані зразки крові племінних свиней миргородської породи племзавода ДП «ДГ ім. Декабристів» Полтавська область. ДНК-типування виконували методами ПЛР-ПДРФ та TaqMan. Результати. Встановлено особливості породи щодо частот алелів генів, високого рівня генетичної мінливості $(H e-0,326)$ та алельного різноманіття (середня кількість алелів на локус - 1,96). Алель KPL2/m, який спричиняє генетичну аномалію ISTS у свиней миргородської породи відсутній, а рецесивний алель RYR1 g.1843T, відповідальний за стресчутливість свиней, зустрічається 3 низькою частотою $(0,04)$. На відміну від інших порід спостерігали відносно високу частоту мінорного алеля CTSK g.15A $(0,16)$ і поліморфізм гену LEP (SNP g.3996 $T>C)(\mathrm{He}-0,455)$. Встановлено статистично значущі асоціації поліморфізмів: $M C 4 R(S N P \quad c .1426 \quad G>A) \quad 3$ 
віком досягнення тваринами маси 100 кг, товщиною шпику та площею «м'язового вічка», GH/BsuRI з віком досягнення 100 кг, і CTSF (SNP g. $22 G>C$ ) 3 площею «м'язового вічка». Спостерігали тенденцію щодо статистично значущих відмінностей між групами свиней 3 різними генотипами LEP (SNP g.2845 A>T) за товщиною шпику $(\mathrm{p}=0,09)$. Висновки. Відновлення генофонду миргородської породи доцільно проводити 3 урахуванням даних SNPS досліджених генів та ї асоціацій з продуктивними ознаками. Для відтворення породи віддавати перевагу свиням із генотипами с.1426 MC4R GA, MC4R AA, g. 22 CTSF CC, g.2845 LEP TT.

Ключові слова: миргородська порода свиней, генетична характеристика, $Q T L, S N P$.

\section{Генетическая характеристика миргородской породы свиней, полученная путем анализа однонуклеотидных полиморфизмов генов}

П. А. Ващенко, В. Н. Балацкий, К. Ф. Почерняев, В. М. Волощук, В. Г. Цибенко, А. М. Саенко, Е. К. Олейниченко, Т. В. Буслик, Г. С. Рудоман

Институт свиноводства и агропромышленного производства НААН Украины, Ул. Шведская могила, 1, Полтава, 36013, Украина

*e-mail: k.f.pochernyaev@gmail.com

Цель. Определить генетические характеристики миргородской породы свиней по 25 SNPs 22 генов и провести ассоциативный анализ генов MC4R (SNP c.1426 G>A), LEP (SNP g.2845 A>T), GH (BsuRIполиморфизм), CTSF (SNP g. 22 G>C) с признаками продуктивности животных. Методы. Для исследований были использованы образцы крови племенных свиней миргородской породы племзавода ГП «Опытное хозяйство им. Декабристов» Полтавская область. ДНКтипирование выполняли методами ПЦР-ПДРФ и TaqMan. Результаты. Установлены особенности породы по частотам аллелей генов, высокого уровня генетической изменчивости $(\mathrm{He}-0,326)$ и аллельного разнообразия (среднее количество аллелей на локус - 1,96). Аллель $K P L 2 / m$, который вызывает генетическую аномалию ISTS, у свиней миргородской породы отсутствует, а рецессивный аллель RYR1 g.1843T, ответственный за стресс-чувствительность свиней, встречается с низкой частотой $(0,04)$. В отличие от других пород наблюдалась относительно высокая частота минорного аллеля CTSK g.15A $(0,16)$ и полиморфизм гена LEP (SNP g.3996 $\mathrm{T}>\mathrm{C})(\mathrm{He}-0,455)$. Установлены статистически значимые ассоциации полиморфизмов: $M C 4 R$ (SNP c.1426 $\mathrm{G}>\mathrm{A})$ с возрастом достижения животными массы 100 кг, толщиной шпика и площадью «мышечного глазка», $\mathrm{GH} / B s u \mathrm{RI}$ с возрастом достижения 100 кг, и CTSF (SNP g.22G>C) с площадью «мышечного глазка». Наблюдалась тенденция статистически значимых различий между группами свиней с различными генотипами LEP (SNP g.2845A > T) по толщине шпика $(\mathrm{p}=0,09)$.

Выводы. Восстановление генофонда миргородской породы, целесообразно проводить с учетом данных SNPs исследованных генов и их ассоциаций с продуктивными признакам. Для воспроизведения породы отдавать предпочтение свиньям с генотипами с.1426 MC4R GA, MC4R AA, g. 22 CTSF CC, g.2845 LEP TT.

Ключевые слова: миргородская порода свиней, генетическая характеристика, QTL, SNP.

\section{REFERENCES}

1. Voitenko S, Petrenko S, Piskovyi M. Local breeds of pigs: conservation and reproduction, Tvarynnytstvo Ukrainy, 2007;(2):70-2.

2. Krylova L, Shulha Y, Lutsenko V, Zhyrkova R, Dudka O, Yavyshchenko $V$, Novikov $V$. Selection pearls of the steppe of Ukraine, Propozytsiia, 2004;(7):83. https://propozitsiya.com/ua/selekciyni-perlini-stepuukrayini.

3. Shulga Y, Dudka O, Maslyuk A, Yvin A. Genotypes of pigs of Ascanian breeding: past and today, Tvarynnytstvo Ukrainy,2012;8(38):76-9.https://elibrary.ru/item.asp?id= 21111894.

4. Ostapchuk PP. Pig breeds and their using, Kyiv: Urozhai, 1980:189 p. https://almazzon.com/p591160344postapchuk-porodi-svinej.html.

5. Voitenko SL. Genesis of the Mirgorod breed of pigs, Visnyk Poltavskoi Derzhavnoi Ahrarnoi Akademii, 2012;2:94-9. doi: 10.31210/visnyk2012.02.19

6. Birta HO, Burhu Yu H. Physico-chemical indices of the longest muscle of the back of pigs of various combinations, Sci. Bulletin of the Lviv National University of Veterinary Medicine and Biotechnologies, 2008;10(3): 13-6.

7. Shcherban T, Vashchenko P. Fattening, slaughtering and meat-lard qualities of Mirgorodska pigs breed and its crosses, Ukrainian Black Sea region agrarian science, 2015;2(2):112-9.

8. Shcherban T, Vovk V. Qualitative indexes of meat and fat of pigs received by attracting the genotype of Mirgorod breed, Tvarynnytstvo Ukrainy, 2014;(8-9):37-40. https:// tvarynnyctvoua.at.ua/publ/8_2014/1-1-0-78

9. Voitenko SL, Vyshnevskyi $L \bar{V}$. Inbreeding in the Mirgorodian pigs, Animal Breeding and Genetics, 2017;54:20815. doi.org/10.31073/abg.54.27

10. Kramarenko SS, Lugovoy SI, Kharzinova VR, Lykhach $V Y$, Kramarenko AS, Lykhach $A V$. Genetic diversity of Ukrainian local pig breeds based on microsatellite markers. Regulatory Mechanisms in Biosystems, 2018; 9(2):177-82. doi: 10.15421/021826.

11. World Organization for Animal Health, Final Report 2017, 85th General Session, Paris, 21-6 May 2017. http:/www.oie.int/fileadmin/Home/eng/About_us/docs/ pdf/Session/2017/A_FR_2017_public.pdf 
12. Walsh PS, Metzger DA, Higuchi R. Chelex 100 as a Medium for Extraction of DNA for PCR-Based Typing from Forensic Material, Biotechniques, 1991;10(4):5069. PMID: 1867860.

13. Short TH, Rothschild MF, Southwood OI, McLaren $D G$, De Vries A, van der Steen H, Eckardt GR,Tuggle CK, Helm J, Vaske DA, Mileham AJ, Plastow GS. Effect of the estrogen receptor locus on reproduction and production traits in four commercial pig lines, J. Anim. Sci, 1997;75(12):3138-42. doi: 10.2527/1997. $75123138 \mathrm{x}$.

14. Fujii J, Otsu K, Zorzato F, de Leon S, Khanna VK, Weiler $J E$, O'Brien PJ, MacLennan DH. Identification of a mutation in porcine ryanodine receptor associated with malignant hyperthermia, Science, 1991;253(5018):44851. doi: $10.1126 /$ science. 1862346 .

15. Kmiec M, Terman A. Association between the prolactin receptor gene polymorphism and reproductive traits of boars, J. Appl. Genet., 2006;47(2):139-41. doi: 10.1007/ bf03194613.

16. Vize PD, Wells JRE. Isolation and characterization of the porcine growth hormone gene. Gene. 1987;55:339-44. doi: 10.1016/0378-1119(87)90294-0.

17. Vykoukalova Z, Knoll A, Dvorak J, Cepica S. New SNPs in the IGF2 gene and association between this gene and backfatthicknessandleanmeatcontentinLarge Whitepigs. J. Anim. Breed Genet. 2006;123(3):204-7. doi: 10.1111/j. 1439-0388.2006.00580.x.

18. Baskin LC, Pomp D. Restriction fragment length polymorphism in amplification products of the porcine growth hormone-releasing hormone gene. J Anim. Sci. 1997;75(8):2285. doi: 10.2527/1997.7582285x.

19. Russo V, Fontanesi L, Scotti E, Beretti F, Davoli R, Nanni Costa L, Virgili R, Buttazzoni L. Single nucleotide polymorphisms in several porcine cathepsin genes are associated with growth, carcass, and production traits in Italian Large White pigs, J.Anim. Sci., 2008;86(12):3300 14. doi: 10.2527/jas.2008-0920.

20. Fontanesi L, Speroni C, Buttazzoni L, Scotti E, Dall'Olio $S$, Davoli $R$, Russo $V$. Association between polymorphisms in cathepsin and cystatin genes with meat production and carcass traits in Italian Duroc pigs: confirmation of the effects of a cathepsin L (CTSL) gene marker, Mol. Biol. Rep., 2012;39(1):109-15. doi: 10.1007/s11033-011-0715-4.

21. Russo V, Fontanesi L, Davoli R, Galli S. Linkage mapping of the porcine cathepsin $\mathrm{F}(C T S F)$ gene close to the QTL regions for meat and fat deposition traits on pig chromosome 2, Anim. Genet., 2004;35(2):155-7. doi: 10.1111/j.1365-2052.2004.01105.x

22. Kim KS, Lee JJ, Shin HY., Choi BH, Lee CK, Kim JJ, Cho BW, Kim TH. Association of melanocortin 4 receptor (MC4R) and high mobility group AT-hook 1 (HMGA1) polymorphisms with pig growth and fat deposition traits, Anim. Genet., 2006;37(4):419-21. doi: 10.1111/j.13652052.2006.01482.x.
23. Kennes YM, Murphy BD, Pothier F, Palin MF. Characterization of swine leptin (LEP) polymorphisms and their association with production traits, Anim. Genet. 2001;32(4):215-18. doi: 10.1046/j.1365-2052. 2001.00768.x.

24. De Oliveira Peixoto J, Facioni Guimarães SE, Sávio Lopes P, Menck Soares MA, Vieira Pires A, Gualberto Barbosa MV, De Almeida Torres R, De Almeida e Silva $M$. Associations of leptin gene polymorphisms with production traits in pigs, J. Anim. Breed. Genet., 2006;123(6):378-83. doi: 10.1111/j.1439-0388.2006. 00611.x.

25. Li X, Kim SW, Choi JS, Lee YM, Lee CK, Choi BH, Kim TH, Choi YI, Kim JJ, Kim KS. Investigation of porcine FABP3 and LEPR gene polymorphisms and mRNA expression for variation in intramuscular fat content, Mol. Biol. Rep., 2010;37(8):3931-9. doi: 10.1007/ s11033-010-0050-1.

26. Syrovnev GI. The genetic polymorphism of FUT1 and MUC4 loci in local population of Ukrainian meat breed pigs. Tsitol Genet. 2014 Sep-Oct;48(5):54-9 MID:25318177.

27. Ruan GR, Xing YY, Fan Y, Qiao RM, He XF, Yang B, Ding NS, Ren JF, Huang LS, Xiao SJ. Genetic variation at RYR1, IGF2, FUT1, MUC13, and KPL2 mutations affecting production traits in Chinese commercial pig breeds. Czech. J. Anim. Sci., 2013;58(2):65-70. doi: 10.17221/6616-CJAS.

28. Sironen A, Vilkki J, Bendixen C, Thomsen B. Infertile Finnish Yorkshire boars carry a full-length LINE1 retrotransposon within the KLP2 gene, Mol. Gen. Genom. 007;278(4):385-91. doi: 10.1007/s00438-0070256-7.

29. Manyatys T, Frych EE, Sembruk Dzh. Methods of genetic engineering. Molecular cloning. Moscow: Myr, 1984:479 p.

30. Balatsky V, Bankovska I, Pena RN, Saienko A, Buslyk T, Korinnyi $S$, Doran $O$. Polymorphisms of the porcine cathepsins, growth hormone-releasing hormone and leptin receptor genes and their association with meat quality traits in Ukrainian Large White breed. Mol. Biol. Rep., 2016;43(6):517-26. doi: 10.1007/s11033-016-3977-z.

31.Peakall R, Smouse PE. GENALEX 6: genetic analysis in Excel. Population genetic software for teaching and research, Mol.Ecol. Not., 2006;6(1):288-95. doi:10.1111/ j.1471-6.2005.01155.x.

32. Sarantseva NK, Balatsky VM, Nor VYu, Olyinichenko $Y e K$. Genetics and population practicability of using $\mathrm{SNP}$ (c. 232T $>\mathrm{A}$ ) of $L E P R$ gene as a marker for further selection for Large White and Myrgorod pig breeds, Anim. Breed. Genet., 2016;52:176-80. doi:10.31073/ abg.52.23.

33. Nor VYu, Metlytska OI, Bilai DV. Molecular genetic aspects of prediction of productivity of pigs of different breeds of Ukraine, Anim. Breed. Genet., 2015;50:14455. http://nbuv.gov.ua/UJRN/rgt_2015_50_23 
34. Rischkowsky B, Pilling D. The state of the world's animal genetic resources for food and agriculture. FAO, 2007, Rome.

35. Rothschild MF, Jacobson C, Vaske DA, Tuggle CK, Wang L, Short TH, Eckardt G, Sasaki S, Vincent A, McLaren D, Southwood O, van der Steen H, Mileham A, Plastow G. The estrogen receptor locus is associated with a major gene influencing litter size in pigs, Proc. Natl. Acad. Sci. USA, 1996;93(1):201-5. doi: 10.1073/pnas.93.1.201.

36. Rothschild MF, Ruvinsky A. The Genetics of the Pig [second edition], Wallingford. Oxfordshire UK: CAB International, 2010:507 p.

37. Domashova LO. Association of reproductive qualities of Large White breed sows with their genotype for estrogen receptor gene (ESR), Zbirnyk Naukovykh Prats VNAU Suchasni Problemy Selektsii Rozvedennia Ta Hihiieny Tvaryn, 2013;2(72):84-9. http://repository.vsau.org/ card.php?lang=en\&id $=6825$

38. Terman, A. Effect of the polymorphism of prolactin receptor (PRLR) and leptin (LEP) genes on litter size in Polish pigs. J. Anim. Breed. Genet. 2005;122(6):400-4. doi: 10.1111/j.1439-0388.2005.00547.x.

39. Zhao Y, Li N, Xiao L, Cao G, Chen Y, Zhang S, Chen Y, Wu $C$, Zhang J, Sun $S, X u X$. FSHB subunit gene is associated with major gene controlling litter size in commercial pig breeds, Sci. China C, Life Sci. 1998;41(6):664-8. doi: 10.1007/BF02882910.

40. Nor VYu, Metlytska OI, Bilai DV. Molecular genetic aspects of prediction of productivity of pigs of different breeds of Ukraine, Anim. Breed. Genet., 2015;50:14455. http://nbuv.gov.ua/UJRN/rgt_2015_50_23.

41. Knoll A, Stratil A, Cepica S, Dvorak J. Length polymorphism in an intron of the porcine osteopontin (SPP1) gene is caused by the presence or absence of a SINE (PRE-1) element, Anim. Genet., 1999;30(6):46278. doi:10.1046/j.1365-2052.1999.00498-5.x.

42. Getmantseva L, Kolosov A, Leonova M, Bakoev S, Klimenko A, Vasilenko V, Radyuk A. Polymorphisms in Several Porcine Genes are Associated with Growth Traits, American Journal of Animal and Veterinary Sciences, 2016;11(4):136-41. doi: 10.3844/ajavsp.2016.136.141.

43. Fontanesi L, Scotty E, Buttazzoni L, Dall'Olio S, Davoli $R$, Russo $V$. A single nucleotide polymorphism in the porcine Cathepsin $\mathrm{K}$ (CTSK) gene is associated with back fat thickness and production traits in Italian Duroc pigs., Mol. Biol. Rep., 2010;37(1):491-5. doi: 10.1007/ s11033-009-9678-0.

44.Dvoŕáková V, Stupka $R$, Šprysl $M$, Čítek $J$, Okrouhlá M, Kluzáková E, Brzobohatý L. The effect of missense mutation G.143C $>$ T in the CTSL gene on production traits without the effect on quality of pork meat, Res. Pig Breed, 2011;5(1):18-21. http://www.respigbreed. cz/2011/1/5.pdf

45. Fontanesi L, Speroni C, Buttazzoni L, Scotti E, Nanni Costa L, Davoli R, Russo V. Association between cathep- $\sin$ L (CTSL) and cathepsin S (CTSS) polymorphisms and meat production and carcass traits in Italian Large White pigs. Meat Sci. 2010;85(2):331-8. doi: 10.1016/j. meatsci.2010.01.023.

46. Piórkowska KL, Ropka-Molik K, Eckert R, Tyra M, Żukowski $K$. The association between polymorphisms of three cathepsins and economically important traits in pigs raised in Poland. Livestock Sci. 2012;150(1-3):316-23. doi:10.1016/j.livsci.2012.09.022.

47.DoranO, Korinnyi SN, Dykan OS, Buslyk TV, Pochernyaev KF, Balatsky $V$, Pena RN. Sequence variation in the cathepsin B (CTSB), L (CTSL), S (CTSS) and K (CTSK) genes in Ukrainian pig breeds, Global J. Anim. Breed. Genet., 2015;3(3):117-24. http://hdl.handle.net/ 10459.1/63472.

48. Galve A, Burgos C, Silio L, Varona L, Rodriguez C, Ovilo C, Lopez Buesa P. The effects of leptin receptor (LEPR) and melanocortin-4 receptor (MC4R) polymorphisms on fat content, fat distribution and fat composition in a Duroc $\times$ Landrace/Large White cross, Livestock Sci., 2012:145(1-3):145-52. doi:10.1016/j. livsci.2012.01.010.

49.Sook-Ha Fan, Yee-How Say Leptin and leptin receptor gene polymorphisms and their association with plasma leptin levels and obesity in a multi-ethnic Malaysian suburban population, J. Physiol. pol., 2014; 33(1):15. doi: 10.1186/1880-6805-33-15.

50. Kim KS, Larsen N, Short T, Plastow G, Rothschild MF. A missense variant of the porcine melanocortin 4 receptor (MC4R) gene is associated with fatness, growth, and feed intake traits. Mammalian Genome. 2000;11(2):1315. doi: $10.1007 / \mathrm{s} 003350010025$.

51. Franco MM, Antunes RC, Silva HD, Goulart LR. Association of PIT1, GH and GHRH polymorphisms with performance and carcass traits in Landrace pigs, J. Appl. Genet., 2005;46(2):195-200. PMID:15876687

52. Konoval OM, Kostenko SO, Spyrydonov VH, Melnychuk $S D$, Hryhoriuk IP. The MC4R gene is a genetic marker for live growth in pigs, Naukovy Bulletin of Uzhhorod University, , Vol. 22. pp. 110-113. https://dspace.uzhnu. edu.ua/jspui/handle/lib/15547?locale=uk

53. Vykoukalova Z, Knoll A, Cepica S. Porcine perilipin (PLIN) gene: Structure, polymorphism and association study in Large White pigs, Czech J. Anim. Sci. 2009; 4(8):359-64. doi: 10.17221/1661-CJAS.

54. Wimmers K, Lin C, Tholen E, Jennen D, Schellander K, Ponsuksili $S$. Polymorphisms in candidate genes as markers for sperm quality and boar fertility, Anim. Genet. 2005;36(2):152-5. doi: 10.1111/j.1365-2.2005.01267.x.

55. Sironen A, Uimari P, Iso-Touru T, Vilkki J. L1 insertion within SPEF2 gene is associated with increased litter size in the Finnish Yorkshire population. J. Anim. Breed. Genet., 2012;129(2):92-7. doi: 10.1111/j.14390388.2011.00977.x.

56. Rui Chen, Shuai Yu, Fa Ren, Xiao Yan Lv, Chuan Ying 


\section{GENETIC CHARACTERIZATION OF THE MIRGOROD PIG BREED, OBTAINED BY ANALYSIS}

Pan Detection of one large insertion/deletion (indel) and two novel SNPs within the SPEF2 gene and their associations with male piglet reproduction traits, Arch. Anim. Breed. 2016;59(2):275-83. doi: 10.5194/aab-59275-2016.

57. Jorgensen C. Patent. US 2006/0275763 A1 United States, Porcine polymorphisms and methods for detecting them. Pub. Date 07.12.2006.

58. Kaspirovich DA, Lebed TL, Doylidov VA. The influence of the paternal genotype on the MUC4 gene locus on the safety of young pigs, Bulletin of Polesye State University. Series of Natural Sciences, 2014, no 2, pp. 3-8.

59. Hao LL, Yu H, Zhang Y, Sun SC, Liu SC, Zeng YZ, Ai YX, Jiang HZ. Single nucleotide polymorphism analysis of exons 3 and 4 of IGF-1 gene in pigs, Genet. Mol. Res., 2011;10(3);1689-95. doi:10.4238/vol10-3gmr1328.

60. Voitenko S, Vishnevsky L. Control of genetic situation in Mirgorod breed pigs, Scientific essay Askania-Nova, 2012;5:195-200. http://nbuv.gov.ua/UJRN/nvan 2012_5\%282\%29_29.

61. Metlytska OI, Nor VYu. Population-genetic study as a justification of ways to preserve the gene pool of pigs of Mirgorod breed. Anim. Breed. Genet. 2013;47:61-73. http://digest.iabg.org.ua/genetics/item/14-47-007.

62. Voitenko SL, Vyshnevskyi LV. Inbreeding in the Mirgorod breed of pigs, Animal Breeding and Genetics, 2017, vol. 54, pp. 208-215. http://dspace.pdaa.edu.ua:8080/ handle/123456789/1963.

63. Kiselyova TY, Podoba BY, Zabludovskiy YY, Terletskiy $V P$, Vorobyev NI, Kantanen $J$. The analysis of $30 \mathrm{mi}-$ crosatellite markers in local cattle populations, Agricultural biology. 2010;(6):20-5. http://www.agrobiology. ru/6-2010kiseleve-eng.html. 